\title{
A Comparison of Root Development in Five Tree Willow Clones Grown in Layered River Sediments
}

\author{
IR McIvor*, R Ward and D Hedderley \\ Plant \& Food Research, New Zealand
}

Submission: June 08, 2021; Published: July 06, 2021

*Corresponding author: Ian McIvor, Scientist, New Zealand Institute for Plant \& Food Research, Private Bag 11600, Palmerston North, New Zealand

\section{Abstract}

Tree willows are important bioengineering tools in bank stabilisation along river and stream banks throughout the temperate world. Willow roots are the functional units that do the stabilising. River bank sediments vary from fine silt through to coarse gravel and boulders, all of which can be shifted by water flow and require stabilisation in a managed river system.

We investigated the early root development of five different tree willow clones Salix matsudana $\times$ alba 'Tangoio'. S. matsudana $\times$ alba 'Moutere'. S. nigra, S. matsudana $\times$ lasiandra (M x L) and S. matsudana $\times$ pentandra (M x P) grown from cuttings in the different riverbank sediments; silt, sand and stones. Our intention was to determine how similar their rooting behaviour was as a precursor to recommendations for their use in bank stabilisation. We hypothesised that root development would be determined by the substrate, rather than the willow genetics resulting in a similar distribution of root in the sediment layers.

Cuttings were grown for 21 weeks in five large planter boxes; each box having three separate compartments. Each box was filled with stones $(0.21 \mathrm{~m}$ depth), overlain with sand $(0.14 \mathrm{~m}$ depth) and topped with silt $(0.35 \mathrm{~m}$ depth). At 21 weeks roots were extracted and sorted into diameter classes ( $>2 \mathrm{~mm}, 1-2 \mathrm{~mm}, 0.5-1 \mathrm{~mm},<0.5 \mathrm{~mm}$ ) according to clone, compartment, and sediment type. Root length and root mass were measured and root length density (RLD) and root mass density (RMD) were calculated. Above ground parameters (stem number, stem mass, leaf area, leaf mass) were also measured.

Roots were distributed in all sediment types but were predominantly present in silt and stone layers. Finest root biomass $(0-0.5 \mathrm{~mm}$ diameter) was greatest in silt and stone layers. Relative proportions of RMD in silt varied between clones from $49 \%$ to $23 \%$, in sand from $32 \%$ to $9 \%$, and in stones from $68 \%$ to $41 \%$. Relative proportions of RLD for roots $>0.5 \mathrm{~mm}$ diameter varied between clones from $47 \%$ to $22 \%$ in silt, $30 \%$ to $4 \%$ in sand, and from $71 \%$ to $43 \%$ in stones. The proportion of mean RMD of finest roots ( $<0.5 \mathrm{~mm}$ diameter) in total mean RMD was 72\% for 'Moutere', 77\% for Nigra, 82\% for 'Tangoio', 84\% for M x L and 87\% for M x P. Mean root mass was highest in 'Tangoio' > M x P > NIgra > 'Moutere' > M x L. Mean shoot mass was highest in 'Tangoio' > 'Moutere' = NIgra > M x P > M x L. Root to shoot ratio was ranked M x P > 'Tangoio' $>$ Nigra > M x L > 'Moutere'.

Keywords: Tree willow; River; Sediment; Root length density; Root mass density; Root shoot ratio

\section{Introduction}

Tree willows (Salix spp.) are important bioengineering tools in bank stabilisation along river and stream banks throughout the temperate world [1-4]. Willows are well adapted to growing in such a changing and movable environment [5-8]. Their trunks can sustain water and flotsam barrages, and their root systems both stabilise the tree and the sediments in which they grow $[2,9,10]$. Salix spp. naturally occur in many temperate Northern Hemisphere countries particularly in riparian habitats. However, in New Zealand, Salix spp. are exotic and so their use in bioengineering resulted from intentional planting of vegetative material along river and stream banks. Thousands of kilometres of streams and riverbanks throughout New Zealand are now lined with willows [11]. Historically the tree willow S. fragilis was planted extensively in river systems, and its root system is very effective in resisting erosive forces and stabilising sediments [11]. The brittle nature of its branches promotes vegetative spread along rivers, which in turn requires more management than less brittle species. Riverine environments are a natural habitat of $S$. nigra, S. pentandra, S. lasiandra and S. matsudana [12] and these species and their hybrids are considered effective tree willow alternatives in New Zealand to the more brittle $S$. fragilis.

Creating or recruiting new riparian forests to improve riverine ecosystem functions can be challenging under modified flow regimes [13]. Both droughts through declining water table 
and floods through prolonged submersion and loosening of root anchorage affect riparian forests $[14,15]$. Salix species are particularly tolerant of these extremes because of their rapid establishment of a root system to adapt to a declining water table and their resilience to uprooting in floods [6]. Controlled cutting experiments have shown that $S$. nigra root system is well adapted to partial and continuous flooding conditions [6]. Survival of S. alba and $S$ viminalis cuttings following flood conditions was shown to depend nonlinearly on both deposition and erosion processes but under severe substrate deposition and erosion cutting survival rate was $42 \%$ [7] demonstrating the resistance of these species, even as one-year-old cuttings, to uprooting and stem breakage.

Willows used as bioengineering tools are typically planted as vegetative cuttings of various sizes [6,16-18]. Poles of $2-5 \mathrm{~m}$ in length can be planted deep into the gravel profile, whereas $1.5 \mathrm{~m}$ whips or $0.5 \mathrm{~m}$ stakes may have sufficient length to only reach the depth of the sand layer or even just the silt. The depth to which the planting material is planted has survival implications when the water table falls during drier periods of the growing season [19]. Poor survival and growth occurred for cuttings encountering sediment moisture deficits, which were more prominent in coarse textured sediments $[7,19]$.

Additional knowledge of how willow roots develop in these sediments can inform our understanding of how the root systems stabilise alluvial sediments and inform clonal choices and planting techniques to accelerate establishment and improve tree stability under adverse flow conditions [8,20].

We investigated tree growth and root development of five tree willow clones in layered river sediments, the layers being silt over sand over coarse gravel, typical of gravel river systems in New Zealand. In determining how similar the rooting behaviour of five tree willow clones bred for riverbank stabilisation are to each other when grown in riverbank sediments layered according to their natural occurrence, we hypothesised that cutting root development will be determined by the substrate, rather than the willow genetics, resulting in a similar amount and distribution of root.

\section{Methods}

To investigate root development of the different tree willow clones in layered riverbank sediments a box trial was set up on a research facility at The New Zealand Institute for Plant \& Food Research Limited (PFR), Palmerston North [8].

Five tree willow clones, Salix matsudana $\times$ alba 'Tangoio' ('Tangoio'). S. matsudana $\times$ alba 'Moutere' ('Moutere'). S. nigra (Nigra), S. matsudana $\times$ lasiandra $(\mathrm{M} \times \mathrm{L}$ ) and $S$. matsudana $\times$ pentandra $(\mathrm{M} \mathrm{x} \mathrm{P})$, were selected to compare their root development in typical layered river sediments. Two of these clones, 'Tangoio' and 'Moutere', are commercial clones and used currently in riparian protection schemes. The remaining three clones, bred for riparian bank stabilisation, are not yet commercialised (Table 1; clones with a seedling number only).

\section{Table 1:}

\begin{tabular}{|c|c|c|c|c|}
\hline Box & Clone & Parentage & Cutting Top Diameter mm & Cutting Bottom Diameter mm \\
\hline 1 & 'Moutere' & S. matsudana $\times$ alba & $30,24,20$ & $33,27,24$ \\
\hline 2 & 'Tangoio' & S. matsudana $\times$ alba & $24,21,23$ & $28,25.26$ \\
\hline 3 & M x & S. matsudana $\times$ lasiandra & $26,31,25$ & $28,33,28$ \\
\hline 4 & Nigra & S. nigra $\times$ S. nigra & $30,22,23$ & $32,25,25$ \\
\hline 5 & M x P & S. matsudana $\times$ pentandra & $29,26,25$ & $31,28,28$ \\
\hline
\end{tabular}

Three $0.9 \mathrm{~m}$ cuttings of each clone having similar stem diameters (Table 1) were pre-soaked in a bucket of water until root buds were visible and planted in plywood boxes on 30 September 2019. Each of five plywood boxes (dimensions $1.6 \mathrm{~m}$ x $0.8 \mathrm{~m} \times 0.4 \mathrm{~m}$ ) were divided into three compartments of equal dimensions [8]. Roots were able to extend between compartments in every sediment layer since the walls between compartments had a large central hole. Each box was filled with river run gravel to a depth of $21 \mathrm{~cm}$, followed by sand to a depth of $14 \mathrm{~cm}$ and finally silt to a depth of $35 \mathrm{~cm}$, being $70 \mathrm{~cm}$ depth in all. The stones, sand and silt were supplied by a local river gravel extraction company. Each clone was confined to a single box with one cutting planted into each compartment. Each cutting was planted to $0.7 \mathrm{~m}$ depth. Box containers were located outside so they were provided with natural rainfall, supplemented with water supplied from an overhead sprinkler twice daily [8]. No mineral nutrients were added to the mix.
During the growth phase, the boxes were weeded and insect pests (giant willow aphids) colonising the cuttings were removed manually.

Plants were harvested 21 weeks after planting the cuttings. For each plant shoot fresh mass and leaf area were measured, and roots in each sediment layer were collected, stored in paper bags and processed separately. Roots were washed and separated into diameter classes $>2 \mathrm{~mm}, 1-2 \mathrm{~mm}, 0.5-1 \mathrm{~mm}$ and $<0.5 \mathrm{~mm}$. Root length (RL) was measured for all diameter classes except $<0.5 \mathrm{~mm}$. Root dry mass (RM) was measured for all diameter classes. Plant shoots and leaves were oven-dried at $70^{\circ} \mathrm{C}$ for 72 hours. Samples for all root diameter classes were separately oven-dried at $70^{\circ} \mathrm{C}$ for $48 \mathrm{~h}$, weighed and RM recorded. Root length (RL) was assessed from RM for roots with diameter $<0.5 \mathrm{~mm}$ by extrapolation from a mean RL: RM calculated from measurements of RL and RM for three samples of roots $<0.5 \mathrm{~mm}$ diameter. The mean density of RM 
and the total RL were calculated for each substrate in the different layers. The root length density (RLD) and the root mass density (RMD) were calculated within the sediment type (silt, sand and stones) for all the root diameter classes and used in the analyses to normalise for the varying depth of each sediment type. RM collected from each cell was attributed to the plant growing in that cell, though there was ready access for root extension between cells within the box. Shoot dry mass for each tree was measured and recorded. The top and bottom diameters of the cuttings were measured at the beginning and the end of the experiment. Data were log-transformed and analysed using ANOVA. Differences were considered significant at $p=0.05$.

Immediately following removal of the roots the cuttings were immersed in water to allow roots to initiate again and compare rate of root development in a non-resistant environment. Photos of the immersed section of the cutting were taken around 25 days following the immersion in water.

\section{Results}

Height growth after 21 weeks was similar among clones except for $S$. matsudana $\times$ lasiandra $(\mathrm{M} \mathrm{x} \mathrm{L)}$ where growth was less for two of the three plants (Figure 1). The largest of the M x L plants had the highest shoot DM (199.4g) of all 15 willow plants, but for the remaining two M x L plants shoot DM was only $29 \mathrm{~g}$ and $33 \mathrm{~g}$, much less than the mean shoot DM of all plants (129g). The clones differed in leaf size and branching pattern (Figure 1), and other above ground parameters (Table 2).

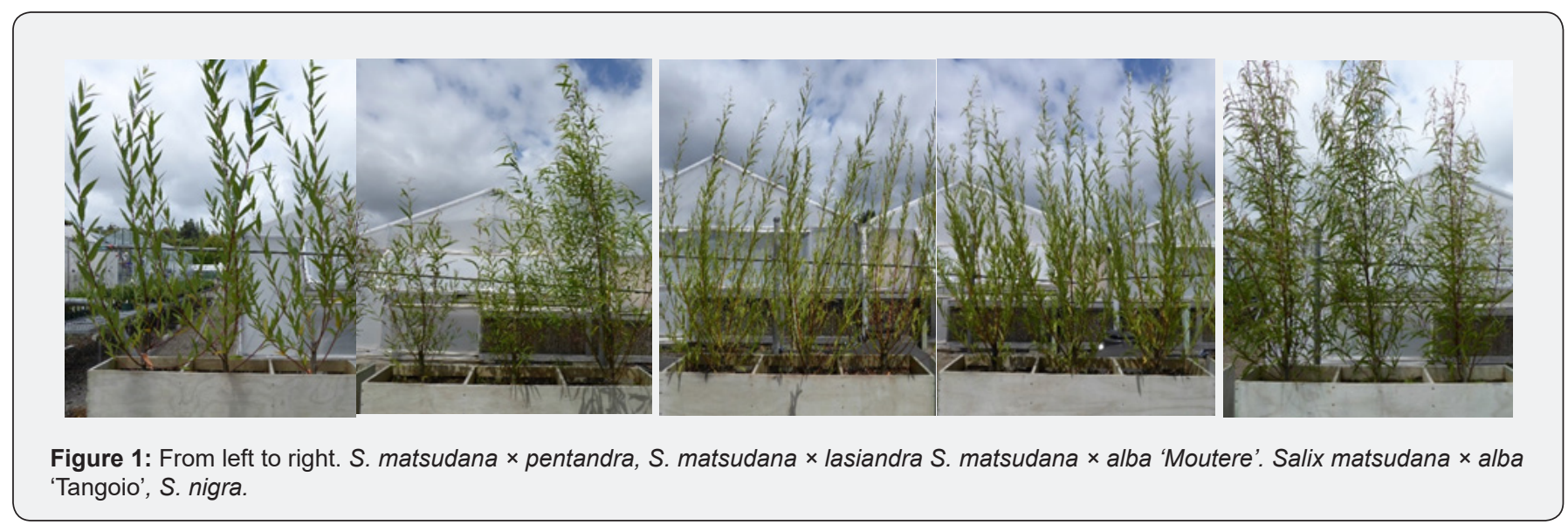

Table 2: Analysis of variance for plant parameters.

\begin{tabular}{|c|c|c|c|c|c|c|c|c|}
\hline Means $(n=3)$ & $\begin{array}{l}\text { Shoot } \\
\text { DM g }\end{array}$ & $\begin{array}{l}\text { Root } \\
\text { DM g }\end{array}$ & $\begin{array}{l}\text { Leaf } \\
\text { DM g }\end{array}$ & $\begin{array}{c}\text { Above Ground } \\
\text { DM g }\end{array}$ & $\begin{array}{l}\text { Leaf Area } \\
\text { cm }^{2}\end{array}$ & Shoot no. & $\begin{array}{c}\text { LA/Shoot } \\
\text { DM }\end{array}$ & Root: Shoot \\
\hline$M \times L$ & 87 & $13.7 \mathrm{a}$ & 47 & 134 & 6642 & $12.0 \mathrm{ab}$ & $140.8 \mathrm{e}$ & 0.43 \\
\hline $\mathrm{M} \times \mathrm{P}$ & 95 & $46.7 \mathrm{c}$ & 52 & 147 & 6372 & $8.3 \mathrm{a}$ & $123.2 \mathrm{~d}$ & 0.35 \\
\hline 'Moutere' & 148 & $15.5 \mathrm{a}$ & 74 & 222 & 5788 & $21.3 \mathrm{c}$ & $78.5 \mathrm{a}$ & 0.09 \\
\hline Nigra & 130 & $30.2 \mathrm{~b}$ & 92 & 222 & 10705 & $9.7 \mathrm{a}$ & $116.2 \mathrm{c}$ & 0.25 \\
\hline 'Tangoio' & 178 & $53.0 \mathrm{c}$ & 90 & 268 & 8779 & $17.0 \mathrm{bc}$ & $97.6 \mathrm{~b}$ & 0.38 \\
\hline Pooled SE & 28 & 4.2 & 16 & 44 & 2075 & 1.9 & 0.3 & 0.12 \\
\hline LSD & 89 & 13.1 & 52 & 139 & 6540 & 5.9 & 1 & 0.36 \\
\hline \multicolumn{9}{|l|}{ ANOVA } \\
\hline Clone F ( 4 and $10 \mathrm{df}$ ) & 1.8 & 18.3 & 1.7 & 1.6 & 1 & 8.5 & 6093.6 & 1.3 \\
\hline $\mathrm{p}$ & 0.216 & $<.001$ & 0.238 & 0.241 & 0.465 & 0.003 & $<.001$ & 0.326 \\
\hline
\end{tabular}

Letters after means indicate which are significantly different at $p=0.05$ (least significant difference test); means with a letter in common were not significantly different.

Most above ground measures did not differ significantly between clones, but the leaf area/shoot dry matter ratio was significantly different for each clone $(\mathrm{p}<0.001)$, and shoot number also differed between clones ( $p=0.003$ ) (Table 2).

Mean root biomass $(\mathrm{N}=3$ ) varied significantly between willow clones (Table 2); being 159g for 'Tangoio', 140g for M x P, 90g for Nigra, 46.5g for 'Moutere' and 40g for M x L. Growth was relatively even between cells in each box except for M x L (Figure 1). Differences in RMD and RLD between cells in each box were not significant.

Most roots were located in the upper silt layer and in the stones, with root mass being lowest in the sand layer (Figure 2, Table 3). 
Biomass of finest roots $(<0.5 \mathrm{~mm}$ diameter $)$ was proportionally greater in silt and stone layers than in sand. Relative proportion of finest root RMD to total RMD was lowest in sand (range 56-77\%; M x L > Nigra > Tangoio > M x P > 'Moutere' and highest in stones (range 78-95\%; 'Tangoio' = M x P > M x L > 'Moutere' > Nigra. In silt the equivalent range was 66-83\% (M x L > Nigra > 'Tangoio' > M x P > 'Moutere'). Root branching was less in sand than the other substrates, and where branching occurred, fine roots typically extended upwards into the silt layer.

Root development varied between clones. The relative proportions of RMD found in silt varied between clones from $49 \%$ to $23 \%$, in sand from $32 \%$ to $9 \%$, and in stones from $68 \%$ to $41 \%$ (Table 3). Likewise, the relative proportions of RLD for roots $>0.5 \mathrm{~mm}$ diameter varied between clones from $47 \%$ to $22 \%$ in silt, $30 \%$ to $4 \%$ in sand and from $71 \%$ to $43 \%$ in stones (Table
3). Finest root $(<0.5 \mathrm{~mm}$ diameter $)$ biomass was $72 \%$ of $\mathrm{RM}$ for 'Moutere', 77\% for Nigra, 82\% for 'Tangoio', 84\% for M x L and $87 \%$ for $\mathrm{M}$ x P.

While the distribution of roots was generally similar for all clones (high in silt and stones, and low in sand), there were significant differences between clones (Table 4) that could be attributed to genetic influences.

Mean root mass per plant ranked 'Tangoio' > M x P > Nigra > 'Moutere' $>\mathrm{Mx} \mathrm{L}$, and similarly root to shoot ratio was ranked $\mathrm{Mx}$ P > 'Tangoio' > Nigra > M x L > 'Moutere'.

\section{Root Mass Density (RMD)}

There were significant differences in RMD between clones ( $p$ $<0.001)$, between substrates $(p<0.001)$, and in the interaction of clone and substrate $(p<0.001)$.

Table 3: Mean distribution (\%) of root mass (RM), root length density (RLD) and root mass density (RMD) between silt, sand and stones for each of the five willow clones.

\begin{tabular}{|c|c|c|c|c|}
\hline Willow & Sediment & $\% \mathrm{RM}$ & $\%$ RLD & $\%$ RMD \\
\hline \multirow{3}{*}{$M \times L$} & silt & 60 & 46 & 45 \\
\hline & sand & 7 & 4 & 13 \\
\hline & stones & 33 & 50 & 42 \\
\hline \multirow{3}{*}{$\mathrm{M} \times \mathrm{P}$} & silt & 34 & 22 & 23 \\
\hline & sand & 61 & 7 & 9 \\
\hline & stones & 11 & 71 & 68 \\
\hline \multirow{3}{*}{ 'Moutere' } & silt & 44 & 16 & 29 \\
\hline & sand & 19 & 30 & 32 \\
\hline & stones & 36 & 54 & 39 \\
\hline \multirow{3}{*}{ Nigra } & silt & 56 & 37 & 41 \\
\hline & sand & 9 & 14 & 17 \\
\hline & stones & 35 & 49 & 42 \\
\hline \multirow{3}{*}{ ‘Tangoio’ } & silt & 63 & 47 & 49 \\
\hline & sand & 5 & 9 & 10 \\
\hline & stones & 32 & 44 & 41 \\
\hline
\end{tabular}

Table 4: Analysis of variance for root mass density (RMD; $\mathrm{g} \mathrm{m}^{-3}$ ) and root length density (RLD; $\left.\mathrm{m} \mathrm{m}^{-3}\right)$ (a) without separation into root diameter classes, and (b) with separation into diameter classes (log-transformed data).

\begin{tabular}{|c|c|c|c|c|}
\hline (a) & Fixed Term & Degrees of Freedom & $\mathbf{p}$ & LSD between Clones \\
\hline \multirow{3}{*}{ RMD } & clone & 4 & $<0.001$ & \multirow{3}{*}{$172 \%$} \\
\hline & substrate & 2 & $<0.001$ & \\
\hline & clone $\mathrm{x}$ substrate & 8 & $<0.001$ & \\
\hline \multirow{3}{*}{ RLD } & clone & 4 & 0.004 & \multirow{3}{*}{$218 \%$} \\
\hline & substrate & 2 & $<0.001$ & \\
\hline & clone $\mathrm{x}$ substrate & 8 & $<0.001$ & \\
\hline \multicolumn{5}{|l|}{ (b) } \\
\hline \multirow{3}{*}{$\begin{array}{c}\text { RMD > } \\
2 \mathrm{~mm} \\
\text { diameter }\end{array}$} & clone & 4 & 0.03 & \multirow{3}{*}{$823 \%$} \\
\hline & substrate & 2 & 0.039 & \\
\hline & clone $\mathrm{x}$ substrate & 8 & $<0.001$ & \\
\hline
\end{tabular}


International Journal of Environmental Sciences \& Natural Resources

\begin{tabular}{|c|c|c|c|c|}
\hline \multirow{3}{*}{$\begin{array}{c}\text { RMD } \\
\text { 1-2mm } \\
\text { diameter }\end{array}$} & clone & 4 & 0.019 & \multirow{3}{*}{$221 \%$} \\
\hline & substrate & 2 & $<0.001$ & \\
\hline & clone $\mathrm{x}$ substrate & 8 & $<0.001$ & \\
\hline \multirow{3}{*}{$\begin{array}{c}\text { RMD } \\
0.5-1 \mathrm{~mm} \\
\text { diameter }\end{array}$} & clone & 4 & $<0.001$ & \multirow{3}{*}{$202 \%$} \\
\hline & substrate & 2 & $<0.001$ & \\
\hline & clone $\mathrm{x}$ substrate & 8 & 0.029 & \\
\hline \multirow{3}{*}{$\begin{array}{c}\text { RMD } \\
<0.5 \mathrm{~mm} \\
\text { diameter }\end{array}$} & clone & 4 & 0.009 & \multirow{3}{*}{$222 \%$} \\
\hline & substrate & 2 & $<0.001$ & \\
\hline & clone $\mathrm{x}$ substrate & 8 & $<0.001$ & \\
\hline \multirow{3}{*}{$\begin{array}{l}\text { RLD > } 2 \mathrm{~mm} \\
\text { diameter }\end{array}$} & clone & 4 & 0.036 & \multirow{3}{*}{$533 \%$} \\
\hline & substrate & 2 & 0.025 & \\
\hline & clone $\mathrm{x}$ substrate & 8 & $<0.001$ & \\
\hline \multirow{3}{*}{$\begin{array}{c}\text { RLD } \\
\text { 1-2mm } \\
\text { diameter }\end{array}$} & clone & 4 & 0.167 & \multirow{3}{*}{$272 \%$} \\
\hline & substrate & 2 & 0.1 & \\
\hline & clone $\mathrm{x}$ substrate & 8 & 0.549 & \\
\hline \multirow{3}{*}{$\begin{array}{c}\text { RLD } \\
0.5-1 \mathrm{~mm} \\
\text { diameter }\end{array}$} & clone & 4 & $<0.001$ & \multirow{3}{*}{$184 \%$} \\
\hline & substrate & 2 & $<0.001$ & \\
\hline & clone $\mathrm{x}$ substrate & 8 & $<0.001$ & \\
\hline \multirow{3}{*}{$\begin{array}{c}\text { RLD } \\
<0.5 \mathrm{~mm} \\
\text { diameter }\end{array}$} & clone & 4 & 0.005 & \multirow{3}{*}{$222 \%$} \\
\hline & substrate & 2 & $<0.001$ & \\
\hline & clone $\mathrm{x}$ substrate & 8 & $<0.001$ & \\
\hline
\end{tabular}

These differences were significant at every root diameter (Table 4). In the sand layer, RMD of M x L was < the other clones;

For M x L, RMD in silt and stones > in sand; for M x P, RMD in stones > in Silt > in Sand; whereas for 'Moutere', RMD in silt, sand stones was similar. For both Nigra and 'Tangoio', RMD in silt and stones $>$ in sand (Figure 3).

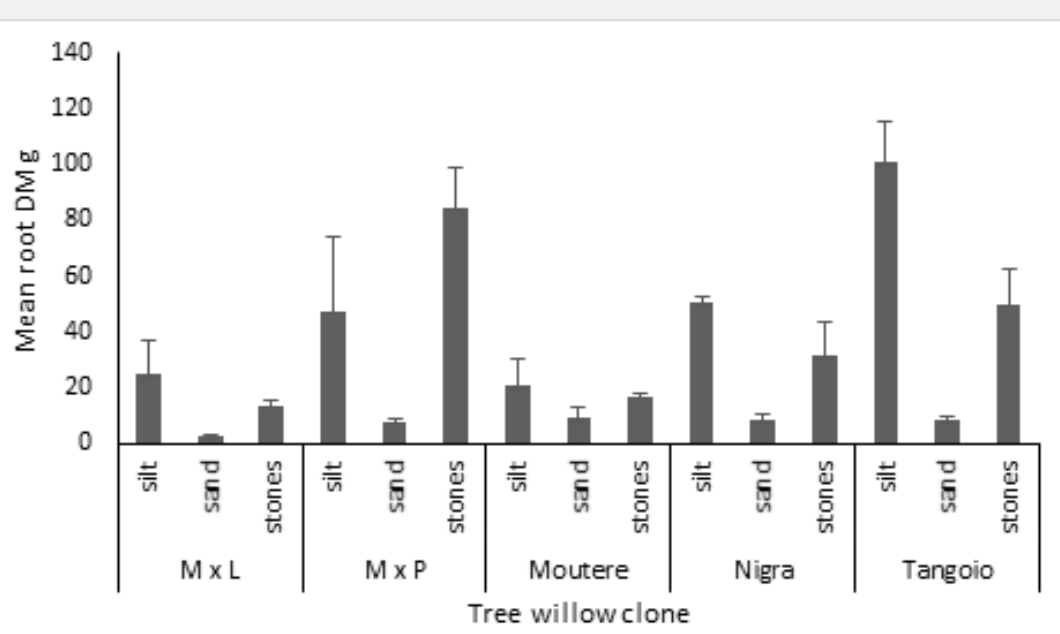

Figure 2: Mean root dry mass present in each of the substrates for each willow clone. Bars are $1 \mathrm{sd}$.

\section{Root Length Density (RLD)}

For RLD, the patterns are generally similar to those for RMD (except for 'Moutere')

There were significant differences in RLD between clones ( $p$
$=0.004)$, between substrates $(p<0.001)$ and in the interaction of clone and substrate $(p<0.001)$; these differences are significant for all root diameters except $1-2 \mathrm{~mm}$ (Table 3) which is more evenly distributed across substrates (Figure 3). 
In the sand layer, RLD for $\mathrm{M} x \mathrm{~L}<$ the other clones. For $\mathrm{M} \times \mathrm{L}$, RLD in silt and stones > in sand; for M x P, RLD in stones > in silt
> in sand; for 'Moutere', RLD in sand and stones > in Silt; for both Nigra and 'Tangoio', RLD in silt and stones > in sand (Table 3).

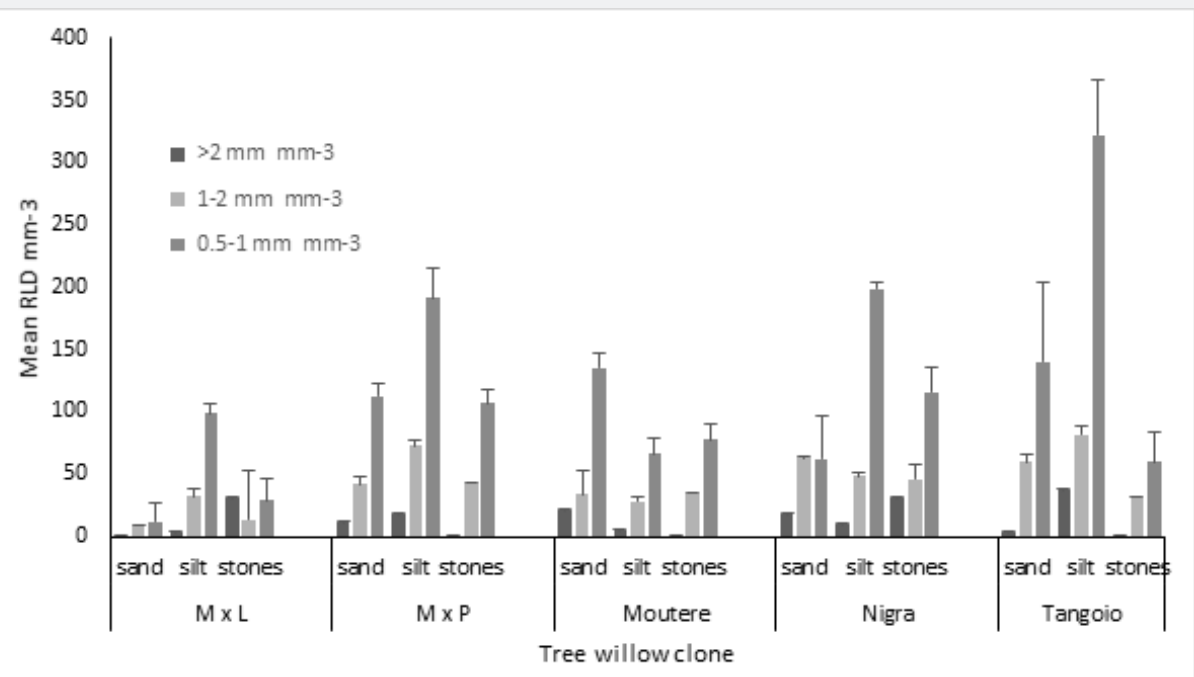

Figure 3: Distribution of mean root length density separated by root diameter for the five willow clones in the different substrates.

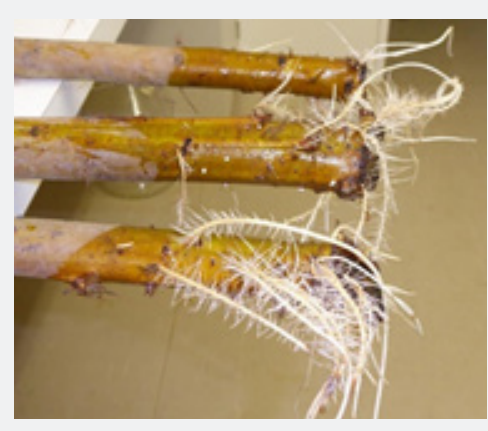

(a)

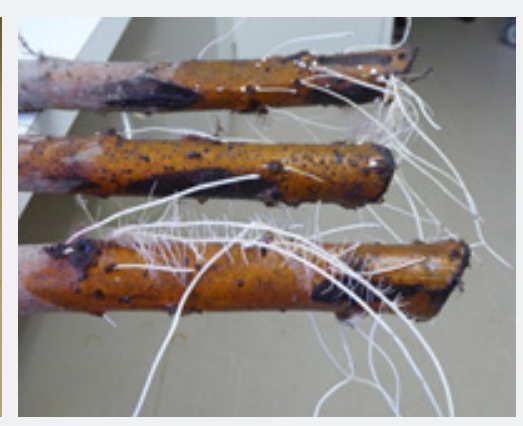

(b) S. matsudana $\times$ pentandra

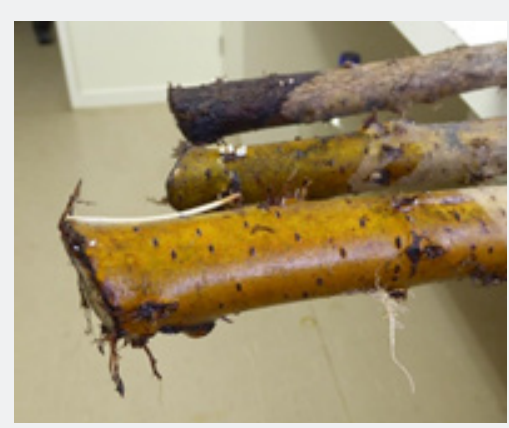

(c) S. matsudana $\times$ alba 'Moutere'

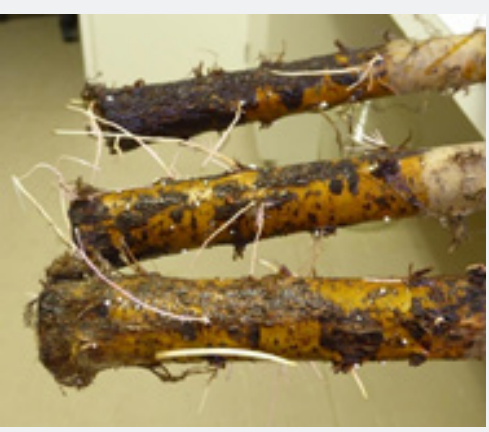

(d) S. matsudana $\times$ alba 'Tangoio'

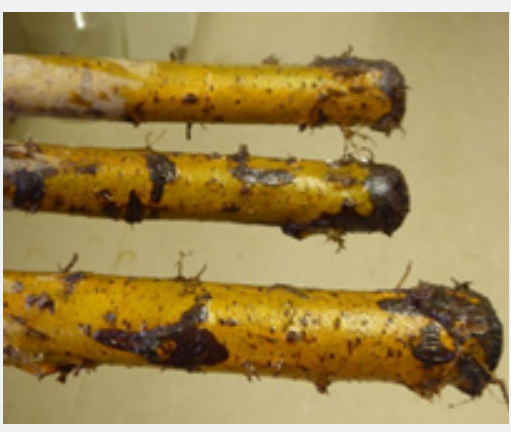

(e) S. matsudana $\times$ lasiandra

Figure 4: Root development of the cuttings of the five tree willow clones after 25 days immersion in water following root removal.

\section{Root development in a non-resistant environment}

The rate of root initiation following immersion of the de-rooted cuttings in water differed among the five clones and differed in the location where root development was most prominent (Figure 4). Root development from the base of the cutting was more prominent in Nigra and M x P than in the other three clones. 


\section{Discussion}

This study investigated root development in five tree willow clones in a controlled environment where sediment depths were uniform and the plants received both natural rainfall and irrigation. Riverine field studies of $S$. nigra [1,21,22] found that moisture deficits reduced height growth, above-ground biomass and leaf area. We hypothesised that substrate characteristics would be more influential in willow root system development than genetics. Our findings confirm that the distribution of root within the three substrates was similar for all clones and that the nature of the substrate was a significant factor determining root growth. However, under the same conditions of growth, there were significant differences in rates of shoot and leaf growth. Under high moisture conditions as provided in this study, fine root presence in the sand layer was low suggesting that soil moisture conditions in the sand layer were less favourable.

However, the roots penetrated easily through the sand layer to the root system, allowing the roots to infiltrate upwards into the silt at a greater distance from the cutting, and so mine a greater soil volume for nutrients and water. In moisture deficit conditions both sand and stones will become difficult environments for root survival unless the water table is close. This study has shown that root initiation is substantial from the bottom of the cutting and root growth is high in a well-watered stony medium. If long cuttings of willows are planted to the depth of the water table, or close to it, satisfactory growing conditions can be maintained during periods when surface layers are moisture deficient. High amounts of fine roots were associate with high soil water contents, whereas soil layers with lower water content and therefore less plant available water had lower fine root densities [23]. Deep rooted trees can hydraulically redistribute water to shallow soils which can sustain fine roots during periods of water stress [23]. Field excavations on the Hutt River, New Zealand showed that willow trees planted from poles to $3 \mathrm{~m}$ depth in river bank sediments had an extensive root system in the surface silt layer and in the deep gravel layer, but had few roots in the sandy intermediate layer [24]. If cuttings are not planted to a depth where initiating roots can reach water easily then the anchorage of the tree will rely on the roots present in the silt layer which is most prone to destabilisation in flood, as well as to drought conditions where a falling water table can result in willow mortality [13].

Development of roots in riverine sediments contrasts with root development in grassland and forest soils where increasing soil density with depth restricts root growth $[25,26]$ In river sediments willows can exploit the more porous media to extend roots at varying depths, but are root growth may be restricted in the deeper riverine sediments with poor water holding capacity unless roots can access the water table quickly.

\section{Conclusion}

a) Early establishment of both shoot and root growth varied significantly between the willow clones, between substrates, and in the interaction clone $\mathrm{x}$ substrate. We conclude that root development of tree willows is influenced by genetics and by the nature of the media in which the tree is growing. Above ground growth (stems, leaves) is not a reliable guide of root growth. Commercial clone S. matsudana × alba 'Tangoio' produced the greatest root growth, followed by the experimental clone $S$. matsudana $\times$ pentandra. Root growth for S. matsudana $\times$ alba 'Tangoio' was more prominent from the section of cutting in the silt layer, in contrast to $S$. matsudana $\times$ pentandra where root growth was more prominent from the bottom of the cutting.

\section{Acknowledgement}

This research project was funded by New Zealand Poplar \& Willow Research Trust, contract 33562.

\section{References}

1. Collins A (2001) The role of willow root architecture and character in root reinforcement potential. Thesis.

2. Pezeshki SR, Shields FD (2006) Black willow cutting survival in streambank plantings, southeastern United States. Journal of the American Water Resources Association 42(1): 191-200.

3. Ahn C, Moser KF, Sparks RE, White DC (2007) Developing a dynamic model to predict the recruitment and early survival of black willow (Salix nigra) in response to different hydrologic conditions. Ecological Modelling 204(3-4): 315-325.

4. Asaeda T, Sanjaya K (2017) The effect of the shortage of gravel sediment in midstream river channels on riparian vegetation cover. River Research and Applications 33(7): 1107-1118.

5. Amlin NA, Rood SB (2001) Inundation tolerances of riparian willows and cottonwoods. Journal of the American Water Resources Association 37(6): 1709-1720.

6. Li SW, Pezeshki SR, Shields FD (2006) Partial flooding enhances aeration in adventitious roots of black willow (Salix nigra) cuttings. Journal of Plant Physiology 163(6): 619-628.

7. Pasquale N, Perona P, Francis R, Burlando P (2014) Above-ground and below-ground Salix dynamics in response to river processes. Hydrological Processes 28(20): 5189-5203.

8. McIvor I, Desrochers V (2019) Tree Willow Root Growth in Sediments Varying in Texture. Forests 10(6): 517.

9. Asaeda T, Gomes PIA, Sakamoto K, Rashid MH (2011) Tree Colonization Trends on a Sediment Bar after a Major Flood. River Research and Applications 27(8): 976-984.

10. Pilipovic A, Zalesny RS, Roncevic S, Nikolic N, Orlovic S, et al. (2019) Growth, physiology, and phytoextraction potential of poplar and willow established in soils amended with heavy-metal contaminated, dredged river sediments. Journal of Environmental Management 239: 352-365.

11. Van Kraayenoord C, Slui B, Knowles F (1995) Introduced forest trees in New Zealand: the willows Salix spp. FRI Bulletin 124: 32.

12. Dickman D, Kuzovkina J (2014) Poplars and willows of the world, with emphasis on silviculturally important species. Poplars and willows: trees for society and the environment. J Isebrands and J Richardson, FAO, p. 634.

13. Grismer ME (2018) Putah Creek hydrology affecting riparian cottonwood and willow tree survival. Environmental Monitoring and Assessment 190(8): 458. 
14. Mahoney JM, Rood SB (1992) Response of A hybrid poplar to watertable decline in different substrates. Forest Ecology and Management 54(1-4): 141-156.

15. Kranjcec J, Mahoney JM, Rood SB (1998) The responses of three riparian cottonwood species to water table decline. Forest Ecology and Management 110(1-3): 77-87.

16. Van Kraayenoord C, Hathaway R (1986) Plant materials handbook for soil conservation, volume 1: Principles and practices. Water and Soil miscellaneous publication No. 93, NWASCO Wellington, pp. 60-67.

17. Oplatka M, Sutherland A (1995) Tests on willow poles used for river bank protection. Journal of Hydrology (NZ) 33(1): 35-58.

18. Schaff SD, Pezeshki SR, Shields FD (2002) Effects of pre-planting soaking on growth and survival of black willow cuttings. Restoration Ecology 10(2): 267-274.

19. Pezeshki SR, Li SW, Shields FD, Martin LT (2007) Factors governing survival of black willow (Salix nigra) cuttings in a streambank restoration project. Ecological Engineering 29(1): 56-65.

20. Calvani G, Francalanci S, Solari L (2019) A Physical Model for the Uprooting of Flexible Vegetation on River Bars. Journal of Geophysical Research-Earth Surface 124(4): 1018-1034.
21. Schaff SD, Pezeshki Sr, Shields FD (2003) Effects of soil conditions on survival and growth of black willow cuttings. Environmental Management 31(6): 748-763.

22. Stokes KE (2008) Exotic invasive black willow (Salix nigra) in Australia: influence of hydrological regimes on population dynamics. Plant Ecology 197(1): 91-105.

23. Gerjets R, Richter F, Jansen M, Carminati A (2021) Hydraulic redistribution by hybrid poplars (Populus nigra $x$ Populus maximowiczii) in a greenhouse soil column experiment. Plant and Soil 463(1-2): 145-154.

24. McIvor I, Jensen M (2021) Root excavation of Salix matsudana $\times$ alba 'Moutere' willow on the Hutt River, Wellington, New Zealand and on the Rangitikei River, Ohakea, New Zealand.

25. Douglas GB, McIvor IR, Potter JF, Foote LG (2010) Root distribution of poplar at varying densities on pastoral hill country. Plant and Soil 333(1-2): 147-161.

26. Plante PM, Rivest D, Vezina A, Vanasse A (2014) Root distribution of different mature tree species growing on contrasting textured soils in temperate windbreaks. Plant and Soil 380(1-2): 429-439.

\section{Your next submission with Juniper Publishers} will reach you the below assets

- Quality Editorial service

- Swift Peer Review

- Reprints availability

- E-prints Service

- Manuscript Podcast for convenient understanding

- Global attainment for your research

- Manuscript accessibility in different formats ( Pdf, E-pub, Full Text, Audio)

- Unceasing customer service

Track the below URL for one-step submission https://juniperpublishers.com/online-submission.php 